\title{
PRZEJRZYSTOŚĆ FINANSÓW PUBLICZNYCH A KSZTALTOWANIE AKTYWNYCH POSTAW OBYWATELSKICH
}

\section{WPROWADZENIE}

Podstawowym celem niniejszego opracowania jest analiza oddziaływania zasady przejrzystości finansów publicznych (tj. rzetelnego informowania o tych finansach) na kształtowanie i zmianę postaw obywatelskich. Tak sformułowany cel wynika z niezwykle istotnego, naszym zdaniem, problemu, mianowicie: w jaki sposób władza publiczna powinna informować o procesach gromadzenia i wydatkowania środków publicznych, mając na uwadze z jednej strony skomplikowaną materię finansów publicznych, z drugiej - różnorodnych pod względem wykształcenia odbiorców tworzacych ogół społeczeństwa. W związku z tym autorzy stawiają hipotezę, że dotychczasowy sposób realizacji zasady przejrzystości finansów publicznych, a więc sposób przekazywania informacji o tych finansach, jest niewłaściwy (niezrozumiały) z punktu widzenia społecznego (adresata). Obecnie w Polsce, zarówno w ujęciu jurydycznym, jak i praktycznym, zasada ta jest w istocie skoncentrowana głównie na mniej lub bardziej profesjonalnym odbiorcy - tzn. takim, który posiada pewien zasób wiedzy na temat tej problematyki ${ }^{1}$, a zatem jest w stanie zrozumieć przekazywane informacje. Ten jej aspekt społeczny jest dostrzegany przez doktrynę ${ }^{2}$. Jakkolwiek o istnieniu przejrzystości finansów publicznych można mówić jako o pewnym założeniu teoretycznym, to z punktu widzenia funkcjonowania demokratycznego modelu państwa oraz społeczeństwa obywatelskiego nastapiło jej wypaczenie. W tym ostatnim kontekście (funkcjonowania państwa demokratycznego) rzetelne informowanie o sprawach finansowych państwa powinno odbywać się przez odpowiednie „komponowanie” informacji oraz zapewnienie do niej dostępu adresatom (będącym przecież mocodawcą władzy publicznej - zob. uwagi poniżej), stosownie do ich wieku i wykształcenia.

Celem naukowego zbadania problemu rzetelnego informowania obywateli $\mathrm{w}$ przedmiocie prowadzonej gospodarki finansowej i podejmowanych decyzji finansowych przez rządzących, naszym zdaniem, uzasadnione było wyjście od

${ }^{1}$ E. Ruśkowski, Zasady budżetowe, w: C. Kosikowski, E. Ruśkowski (red.), Finanse publiczne i prawo finansowe, Warszawa 2008, s. 301.

${ }^{2}$ E. Kornberger-Sokołowska, Budżety jednostek samorzqdu terytorialnego, w: E. Ruśkowski (red.), System prawa finansowego. Prawo finansowe sektora finansów publicznych, t. 2, Warszawa 2010, s. 254; E. Malinowska-Misiag, W. Misiag, Finanse publiczne w Polsce, Warszawa 2007, s. 46-47. 
prezentowanej w naukach ekonomicznych, w tym nauki o zarządzaniu, koncepcji/teorii mocodawca - agent (principal-agent) dla sektora publicznego ${ }^{3}$, w którym mocodawca jest społeczeństwo/obywatele, a agentem - władza publiczna (politycy).

Przyjęliśsmy, że aby mocodawca (społeczeństwo) czuł się odpowiedzialny za sprawy publiczne oraz - co jest z tym związane - mógł skutecznie motywować władzę publiczną (polityków) do podejmowania bądź korygowania decyzji, mocodawca bowiem musi być społeczeństwem obywatelskim. Podstawowym wymogiem jego istnienia w demokratycznych państwach jest/powinna być odpowiednia edukacja (rzetelna informacja) na temat spraw publicznych, w tym finansów publicznych. Ten warunek związany jest ściśle z przejrzystościa, czyli jawnością materialna ${ }^{4}$, która oznacza prezentację istotnych w danym kontekście informacji i danych w sposób zrozumiały i przystępny dla obywateli. Podkreślić trzeba, że bez rzeczywistej jawności (przejrzystości) działań władzy i informacji na temat finansów publicznych nie można mówić o edukacji obywatelskiej i kształtowaniu się rzeczywistych postaw obywatelskich. Z drugiej zaś strony stałe rzetelne (przejrzyste, zrozumiałe) informowanie/edukowanie wpływa na stopniowe poszerzanie zakresu zrozumiałych dla obywatela informacji (jawności w sensie materialnym). Istnienie realnych (nie tylko pozornych czy też szczątkowych) i rozwiniętych form społeczeństwa obywatelskiego powoduje stan/poczucie odpowiedzialności i wpływu obywateli na stan spraw, w tym finansów publicznych (odpowiedzialność globalna społeczeństwa).

Kończąc tę część rozważań, pragniemy zauważyć, że podejmowana w niniejszym artykule problematyka stanowi element składowy zainicjowanych przez autorów szerszych badań na temat roli wartości moralnych w dystrybucji środków publicznych przez władzę publiczna. Badania te opierają się m.in. na analizie danych pochodzacych z przeprowadzonych ankiet (badania empiryczne), aczkolwiek na potrzeby tego artykułu autorzy wykorzystali niereaktywne (nieempiryczne) metody badawcze skupiające się na analizie literatury i regulacji prawnych obowiązujących w Polsce.

\section{CZYNNIKI WPLYWAJACE NA PROCESY PODEJMOWANIA DECYZJI FINANSOWYCH PRZEZ WLADZE PUBLICZNĄ: ROLA KOMUNIKOWANIA SIE}

We współczesnych państwach normalnym i powszechnym zjawiskiem jest analizowanie decyzji władz publicznych, które mają charakter finansowy, tj. powodują znaczące skutki finansowe. Decyzje takie wywołują niejednokrotnie

\footnotetext{
${ }^{3}$ B.R. Weingast, M. Moran, The congressional-bureaucratic system: a principal-agent perspective, „Public Choice” 44, 1984, s. 147-192; T. Moe, The new economics of organization, „American Journal of Political Science” 28, 1984, s. 739-777.

${ }^{4} \mathrm{~W}$ przeciwieństwie do niej jawność formalna to prezentacja danych i informacji w dowolnej formule, układzie itd. Zapewnia ona wprawdzie przekazywanie informacji i danych, to niejednokrotnie często ma charakter wyspecjalizowany lub de facto pozorowany.
} 
wiele emocji, nie tylko wśród naukowców i ekspertów czy samych polityków, lecz także wśród obywateli, którzy są szczególnie zainteresowani wówczas, gdy rzutują one na ich sytuację osobistą.

Decyzje o wymiarze finansowym, które są szeroko dyskutowane, dotycza m.in.:

- ustalenia zakresu gwarantowanych i finansowanych przez państwo świadczeń zdrowotnych;

- przesłanek udzielania oraz wysokości różnorodnych świadczeń socjalnych (np. zapomóg, zasiłków itd.) wypłacanych ze środków publicznych;

- zasad finansowania ubezpieczenia społecznego obywateli oraz przesłanek (w postaci np. wieku, stażu pracy, stopnia utraty zdrowia itd.), które uprawniaja do pobierania emerytury lub renty;

- zmian w systemie podatkowym, a przede wszystkim określenia zasad opodatkowania dochodów osób fizycznych oraz przedsiębiorstw oraz ewentualnych ulg i zwolnień podatkowych.

Decyzje władz publicznych podejmowane w wymienionych powyżej obszarach $\mathrm{w}$ istocie (tj. w sensie obiektywnym) nigdy nie moga być ocenione jako jednoznacznie pozytywne albo negatywne. Twierdzenie to wynika z faktu istnienia różnorodnych kryteriów ocen. Niejako pierwszoplanowo wprowadzane regulacje prawne oceniane są przez pryzmat ich społecznych skutków, ponieważ wpływają one na poziom warunków życia, tj. uprawnień i obowiązków mieszkańców oraz przedsiębiorców w danym kraju. Przy czym ich pozytywne lub negatywne oddziaływanie (skądinąd także w znaczącej mierze subiektywne) na poszczególne kategorie podmiotów także jest różne. Innym kryterium oceny jest najczęściej aktualna, a czasami jedynie - przyszła wydolność finansowa/budżetowa danego państwa. W takich przypadkach, niezależnie od dokonywanych przez specjalistów obliczeń i przewidywań, w rzeczywistości skutki decyzji zawsze odbiegają na plus lub na minus od przewidywanych zamierzeń. Jako przykład można tu podać reformę opieki zdrowotnej w USA (tzw. Obamacare ${ }^{5}$ ), której skutki zarówno dla objętych systemem opieki, jak i dla budżetu Stanów Zjednoczonych dalekie są od planowanych w tym względzie efektów ${ }^{6}$.

Poniżej prezentujemy schemat, który przedstawia podstawowe (kluczowe), naszym zdaniem, determinanty podejmowania decyzji finansowych (w tym tworzenia prawa finansów publicznych) przez władzę publiczną. Można stwierdzić, że są to czynniki (uwarunkowania) tworzace swoiste środowisko procesów zarządzania przez władze publiczne. Najbardziej jednak istotne są różnorodne związki (relacje) występujące pomiędzy określonymi uwarunkowaniami. One bowiem, obok danych (samych) klas czynników, współtworza

\footnotetext{
${ }^{5}$ Patient Protection and Affordable Care Act podpisany przez Prezydenta USA w 2010 r., a wprowadzany w życie stopniowo od 1 października $2013 \mathrm{r}$.

${ }^{6}$ Kaiser Health Tracking Poll, December 2013, The Henry Keiser Family Foundation 2013, $<$ http://www.kff.org/health-reform/poll-finding/kaiser-health-tracking-poll-december-2013/> [dostęp: 6.09.2017]; S. Cornwell, D. Morgan, Obamacare website gets new tech experts; oversight pressure grows, Reuters 2013, <http://www.reuters.com/article/us-usa-healthcare-surge-idUSBRE99U16R20131031> [dostęp: 8.09.2017].
} 
takie, a nie inne okoliczności wpływające na podejmowanie decyzji finansowych w danym miejscu i czasie. Jednym z rodzajów tych zwiąków są wskazane na schemacie korelacje (sprzężenia dwukierunkowe), które - jak zaznaczono - zostały uznane za dodatkowe uwarunkowania podejmowania decyzji.

\section{Schemat}

Uwarunkowania ('́rodowisko) podejmowania decyzji finansowych przez władzę publiczną

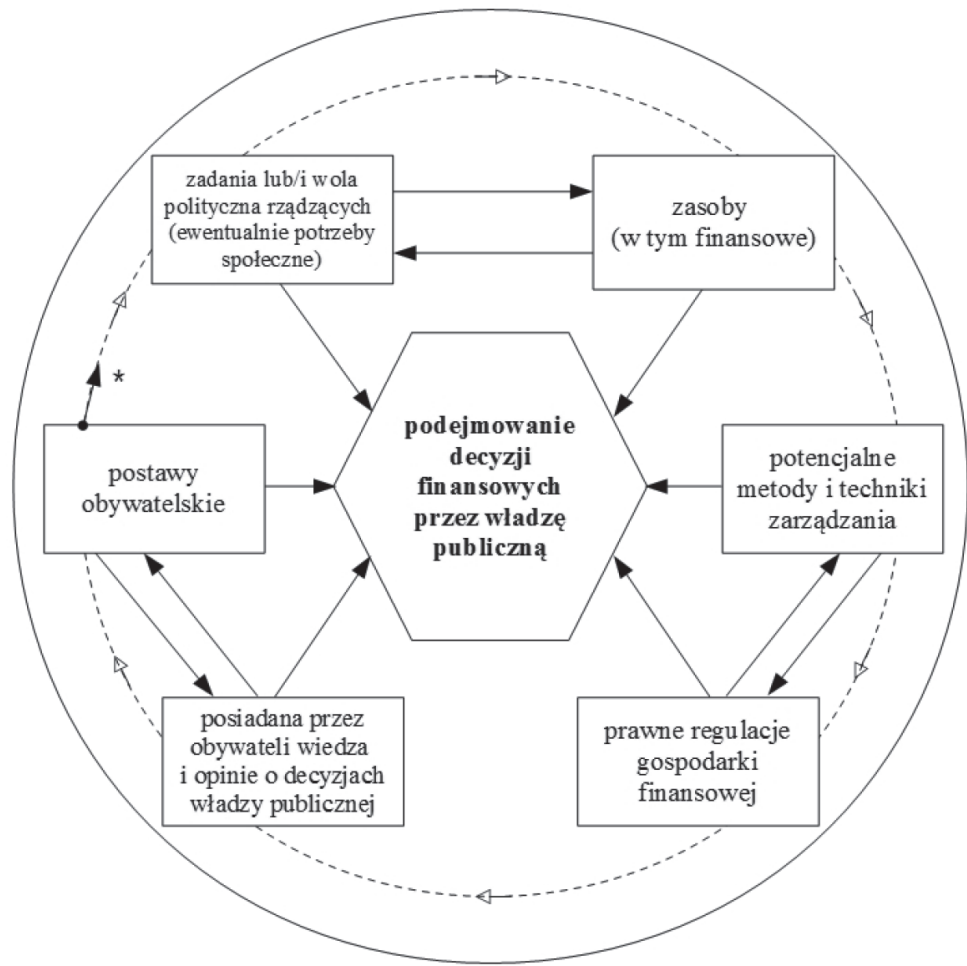

* początek cyklu występowania przesłanek wpływających na podejmowanie decyzji finansowych

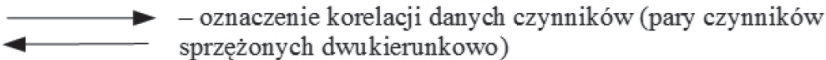

Źródło: opracowanie własne.

Zaprezentowane podejście wymaga dodatkowych objaśnień. Mianowicie zaznaczona kowariancja we wszystkich „parach czynników” w określonych warunkach i czasie ustala w istocie obszar, czy też ramy, potencjalnych zachowań decyzyjnych. To znaczy że chociaż z abstrakcyjnego punktu widzenia określone kategorie (klasy) czynników mogą być rozpatrywane oddzielnie bądź łącznie, to w płaszczyźnie realnej (rzeczywistej) podejmowanie decyzji determinowane jest nie tyle poszczególnymi klasami czynników, ile de facto występującymi pomiędzy nimi współzależnościami, które tworzą takie, a nie 
inne, tj. specyficzne okoliczności. Każda z korelacji ma odmienną rolę i znaczenie w kształtowaniu warunków decyzji:

1) relacja: zadania/wola polityczna rzadzacych - zasoby na zarządzajacych (przedstawicielach władzy publicznej) wymusza:

a) z jednej strony - określenie wydatków o znaczeniu priorytetowym i podejmowanie działań w kierunku ich racjonalizacji, która przybierać może różnorodne formy;

b) z drugiej zaś strony - intensyfikację działań zmierzających do zwiększenia potencjału finansowego (m.in. w postaci pozyskiwania nowych źródeł dochodów).

Trzeba przy tym oczywiście pamiętać, że to szczególnie zasoby finansowe mogą ograniczać zarówno zakres zadań, jak i w ogóle możliwość ich realizacji, pomimo wcześniejszych deklaracji polityków (woli politycznej), np. w trakcie kampanii wyborczej;

2) relacja: potencjalne metody i techniki zarzactania - prawne regulacje gospodarki finansowej wyznacza natomiast warianty możliwych w danych warunkach i czasie działań i decyzji (zachowań) w zakresie prowadzonej publicznej gospodarki finansowej i jej kierunków. Wypracowane modele służyć mogą wprawdzie poprawie jakości zarządzania, aczkolwiek ich zastosowanie nie zawsze jest możliwe z uwagi na obowiąujące przepisy wyznaczające ramy zachowań zarządczych. Zaznaczyć w tym miejscu należy, że bardzo często wskazuje się, że przepisy normujące zakres, a w szczególności procedury decyzyjne w sektorze publicznym, „nie nadążaja” za modelami efektywnego i skutecznego zarządzania finansami. W tym kontekście trzeba zwrócić uwagę na ogólną (uniwersalna) regułę, że organy administracji publicznej działają wyłącznie na podstawie i w granicach prawa. Oznacza to, że nie obowiąuje tu uznawana w sektorze niepublicznym zasada, że dozwolone jest to, co nie jest zakazane. W konsekwencji zastosowanie określonych (nowoczesnych lub modyfikowanych) metod i technik zarządzania w podejmowaniu decyzji finansowych władzy publicznej wymaga najczęściej zmian przepisów, które umożliwią ich wykorzystanie;

3) relacja: p o st a w y o b y w a t e l s ki e-posi a d a n a przez obywateli w i e d z a i o pinie o d e c y z j a c h władzy publicznej finalnie określa (w sposób ograniczajacy) ramy podejmowania decyzji przez władzę publiczną i odpowiedzialności za nie. Zależność tę można rozpatrywać w kilku aspektach ${ }^{7}$. Uwzględniając jednak przedmiot naszych rozważań, najistotniejsze jest, aby łącznie:

a) rządzący uwzględniali preferencje i/lub postawy obywateli (wyborców);

b) realnie (a nie tylko pozornie) komunikowali się z obywatelami w toku (procesie) podejmowania decyzji. Przestrzeganie wskazanych wymogów warunkuje m.in. społeczną akceptację prowadzonej polityki finansowej, co z kolei wpływa na skuteczność decyzji (przestrzeganie prawa).

\footnotetext{
${ }^{7}$ Decyzje zarządcze rozpatrywać można m.in. z zastosowaniem teorii kosztów transakcyjnych, agencji oraz najszerzej - zdaje się - akcentowanej teorii wyboru publicznego. Zob. J.E. Stiglitz, Ekonomia sektora publicznego, Warszawa 2004, s. 184; J.M. Buchanan, R.A. Musgrave, Finanse publiczne a wybór publiczny. Dwie odmienne wizje państwa, Warszawa 2005, s. 55-124 i 163.
} 
Niezależnie od wyróżnienia relacji wskazanych elementów (par czynników), wszystkie one współtworzą pewnego rodzaju zamknięty i powtarzalny cykl, składający się na proces podejmowania decyzji finansowych przez władzę publiczną. Dlatego też na przedstawionym wykresie przez klasy czynników poprowadzono przerywany okrag z zaznaczonym kierunkiem zgodnym z ruchem wskazówek zegara. Zaznaczyć jednak należy, iż sama powtarzalność cyklów (w sensie zasady) nie oznacza ani nie może oznaczać, że owe cykle są identyczne. Każda z par czynników bowiem w wyniku poprzedniego procesu (cyklu) podejmowania decyzji może ulec modyfikacji, co oznacza, że również kolejne decyzje finansowe będa inne. Jest to oczywiste, mając na uwadze fakt zmienności wyborów politycznych obywateli oraz zmienności polityki finansowej.

Uznaliśmy ponadto, że sam cykl rozpoczyna się od określonych postaw obywatelskich, do których w szczególności należy udział obywatela w wyborach swoich przedstawicieli jako przyszłych potencjalnych rządzących, tworzacych władze publiczne. Te ostatnie najczęściej dokonują analizy/oceny decyzji finansowych przede wszystkim przez pryzmat możliwości kształtowania i wykorzystywania potencjału finansowego do realizacji powiększającej się stale puli zadań publicznych (relacja: zadania/wola polityczna rządzących - zasoby). Jest to oczywiste, ponieważ zasoby finansowe w połączeniu ze sprawnym i skutecznym systemem zarządzania i przepisami prawnymi (relacja: potencjalne metody i techniki zarządzania - prawne regulacje gospodarki finansowej) pierwszoplanowo determinują możliwość osiagnięcia zakładanych celów.

W dalszej części artykułu skupimy się jednak na kwestiach związanych z komunikowaniem się władzy publicznej z obywatelami, a w szczególności przejrzystością komunikacji. Nie jest to zagadnienie, któremu poświęcano dotychczas należyta uwagę w badaniach prowadzonych w obszarze finansów publicznych ${ }^{8}$, jakkolwiek jest to niezbędny element funkcjonowania współczesnego (nowoczesnego) społeczeństwa demokratycznego, w tym ciagłego kształtowania się postaw obywatelskich. To one powinny mieć wpływ zarówno na ocenę działalności władzy publicznej, jak i motywowania jej do określonych działań.

\section{KOMUNIKACJA POMIĘDZY WEADZĄ PUBLICZNA A OBYWATELAMI (PRZEJRZYSTOŚĆ ZAMIERZEŃ I DZIAEAŃ) - UZASADNIENIE, ROLA I CZYNNIKI ZNIEKSZTALCAJĄCE}

Jak już ustaliliśmy, podstawowe (kluczowe) znaczenie w kształtowaniu się adekwatnych, w danych warunkach i czasie, postaw obywatelskich ma właściwy przepływ informacji. Ten właściwy przepływ informacji to realne, a nie tylko pozornie (czy pozorowane) komunikowanie się władzy publicznej ze społeczeństwem. Spełnienie tego warunku decyduje o:

${ }^{8}$ Przedstawiciele nauki (niejako opowiadający się za regulacjami prawnymi w tym zakresie) skupiali się na analizie formalnych/prawnych reguł przejrzystości finansów publicznych - zob. na temat pkt IV artykułu. 
- realnym kształtowaniu się, w tym korekcie lub zmianie postaw obywatelskich;

- faktycznym istnieniu społeczeństwa obywatelskiego;

- w miarę świadomym, tj. opartym na wiedzy i poglądach, oddziaływaniu społeczeństwa na władzę publiczną (polityków).

Inaczej ujmujac - przekazywane przez władze publiczne informacje na temat zamierzeń, ich planowanych skutków czy też aktualnych oraz przyszłych wyników (w tym finansowych) podjętych działań powinny być przejrzyste, tzn. zrozumiałe (szerzej zob. pkt IV). W praktyce, niestety, tak nie jest. Władza publiczna (politycy) bowiem z różnych przyczyn nie jest bądź to w ogóle, bądź wystarczająco zdeterminowana do podejmowania decyzji racjonalizujących gospodarkę finansowa państwa ${ }^{9}$.

Problem z rzetelnym (realnym) informowaniem obywateli dotyczy skądinąd nie tylko spraw finansowych. Jest on bezpośrednio związany ze zjawiskiem zniekształcania informacji z powodu różnych przyczyn. Część z nich ma charakter obiektywny, a część subiektywny. Zgodnie z przywołaną na wstępie teoria agencji czynniki obiektywne niepełnego lub nieprzejrzystego przekazywania informacji obywatelom (mocodawcy) to niewystarczajacy stan wiedzy na dany temat przez przekazującego tę informację ${ }^{10}$. Przez „nieprzejrzystość" rozumiemy przy tym m.in. przekazywanie bardzo wielu, nieuporządkowanych informacji, w których najistotniejsze kwestie bądź to w ogóle się nie pojawiaja, bądź też - rzadziej - gubią się w masie danych. Przyczyny subiektywne sprowadzają się zaś do celowego zatajenia (nieupubliczniania) niektórych informacji. Dzieje się tak przeważnie dlatego, że ewentualne przekazanie tych informacji mogłoby wpłynąć na negatywną ocenę działań władzy przez obywateli (wyborców) i co za tym idzie - spowodować poniesienie politycznej odpowiedzialności przed wyborcami (mocodawca).

Nie można oczywiście zapominać, że bodźce motywacyjne przedstawicieli/agentów (tj. władzy publicznej, polityków) nigdy nie będą i nie mogą być w całości zbieżne z interesami mocodawców (społeczeństwa). Bezsprzecznie jednak kontrola nad działaniami władzy publicznej (polityków) jest konieczna. Ponadto przejrzystość informacji oraz kształtowanie się wiedzy obywatelskiej powodują niejako dystrybucję części władzy ${ }^{11}$, ponieważ przedstawione zależności pomiędzy rzetelną informacją a postawami obywatelskimi przebiegają również w odwrotnym kierunku (por. przerywany okrag). Decyzje władzy publicznej (polityków), w tym decyzje finansowe, oddziałują na odpowiedzialność polityków, kształtowanie się odpowiedzialności obywatelskiej oraz umacnianie instytucji społeczeństwa obywatelskiego ${ }^{12}$.

${ }^{9}$ Szerzej omawiają to: J.M. Buchanan, R.D. Tollison, The Theory of Public Choice: Political Applications of Economics, Ann Arbor 1972.

10 Stan ten może wynikać zarówno z braku lub zniekształcenia informacji przekazanych sprawującym władzę z niższego szczebla zarządzania albo z braku wystarczajaccej wiedzy sprawującego władzę co do ważności/wagi poszczególnych danych (które są przecież zróżnicowane).

11 F. Fukuyama, Budowanie państwa. Wtadza i ład międzynarodowy w XXI wieku, Poznań 2005 , s. 69.

12 J.M. Salachna, M. Tyniewicki, Moralność jako element podejmowania decyzji finansowych w sektorze publicznym, „Prawo Budżetowe Państwa i Samorządu” 2016, nr 3(4), s. 16-17, <http:// apcz.pl/czasopisma/index.php/PBPS/article/view/PBPS.2016.012/10388> [dostęp: 8.09.2017]. 


\section{ZASADA PRZEJRZYSTOŚCI W POLSCE - INFORMOWANIE CZY DEZINFORMACJA?}

Zasada przejrzystości jest elementem szerszej zasady, jaką jest jawność finansów publicznych. W szerokim ujęciu jawność finansów publicznych zapewnia kontrolę parlamentarną i społeczną nad procesami gromadzenia i wydatkowania środków publicznych ${ }^{13}$. Podkreśla się przy tym, że: „presja społeczna okazuje się instrumentem silniejszym od bardzo nawet wnikliwej kontroli wewnętrznej"14. Gwarantuje więc ona poniekąd (częściowo) funkcjonowanie demokratycznego państwa prawnego, którego elementem jest społeczeństwo obywatelskie.

Zasada jawności uregulowana została w art. 33 ust. 1 ustawy z 27 sierpnia 2009 r. o finansach publicznych ${ }^{15}$, a sposób jej realizacji w aspekcie formalnym rozumianym jako obowiąek publikacji określonych danych czy zachowania jawności procedur finansowych wynika z art. 34-38c ustawy. Warto też w tym miejscu podkreślić, że jawność należy do tzw. wartości konstytucyjnych (zob. art. 61 Konstytucji $\left.\mathrm{RP}^{16}\right)$.

Oczywiste jest, że samo nałożenie na władzę publiczną obowiązków publikacyjnych w postaci ujawniania opinii publicznej danych na temat finansów państwa i prowadzonej gospodarki finansowej nie stanowi gwarancji efektywnego realizowania tejże dyrektywy. Przy czym, w naszym przekonaniu, pojęcie efektywności w analizowanym kontekście powinno odnosić się do rzetelnego (jasnego) przekazywania/prezentowania danych różnym grupom adresatów. To zaś oznacza zasadę przejrzystości (jawności materialnej). Na marginesie zaznaczyć należy, że w tzw. nauce zachodniej częściej się można spotkać z pojęciem zasady szczegółowości lub specyfikacji ${ }^{17}$.

Doktryna finansowa obok jawności formalnej akcentuje również zasadę przejrzystości, a także podkreśla jej społeczno-kontrolne funkcje. Jednak analiza poglądów na tle ich realizacji (praktyki) prowadzi do konstatacji, że mamy do czynienia bardziej z postulatami niż praktycznym ich stosowaniem. Zarówno tzw. ustawodawca, jak i kolejne rządy wydają się bagatelizować społeczny aspekt zasady przejrzystości. Wiele do życzenia pozostawia także edukacja w tym względzie w ramach zajęć poświęconych finansom publicznym na studiach prawniczych, ekonomicznych bądź administracyjnych. Ogranicza się ona $\mathrm{w}$ zasadzie, tak jak zreszta przeważnie u przedstawicieli doktryny, do wskazania regulacji prawnych określających instrumenty realizacji tej zasady, wśród których wymienić można:

${ }_{13}$ P.G. Gaudemet, J. Molinier, Finanse publiczne, Warszawa 2000, s. 238-239; M. Weralski, Finanse publiczne i prawo finansowe, Warszawa 1984, s. 65-71 i 183-184.

${ }^{14}$ E. Malinowska-Misiag, W. Misiag, op. cit., s. 46-47.

15 T.jedn.: Dz. U. 2016, poz. 1870 ze zm.

${ }^{16}$ Konstytucja Rzeczypospolitej Polskiej z 2 kwietnia 1997 r. (Dz. U. Nr 78, poz. 483 ze zm., sprost.: Dz. U. 2001, Nr 28, poz. 319).

${ }^{17}$ D. Strasser, The Finances of Europe, Luxembourg 1992, s. 55; P.M. Gaudemet, J. Molinier, op. cit., s. 238. 
- odpowiednią szczegółowość podziału dochodów i wydatków publicznych;

- prowadzenie rachunkowości budżetowej;

- przedkładanie właściwych sprawozdań z operacji środkami publicznymi.

Natomiast kwestie skuteczności (zrozumiałości) publikowanych danych pozostaja poza obszarem zainteresowania. Taki stan powoduje, że zasada przejrzystości rzeczywiście realizowana jest z jednej strony (przedmiotowo) - w bardzo formalny sposób, z drugiej zaś (podmiotowo) - z punktu widzenia jedynie profesjonalnych odbiorców, tzn. posiadających określony zasób wiedzy z zakresu problematyki finansów publicznych. Zważywszy jednak na przyjęty sposób prezentacji danych, uważamy, że nawet owi profesjonaliści moga mieć problemy z rzeczywistą identyfikacją i oceną stanu finansów publicznych (w szczególności finansów państwa) bądź prowadzonej polityki finansowej przez rządzących.

Biorac pod uwagę interesy obywatela nieposiadającego profesjonalnej wiedzy o procesach gospodarowania środkami publicznymi, można wskazać na kilka ogólnych barier realizowania zasady przejrzystości finansów publicznych (skutecznego informowania). Należą do nich:

- ogrom (w sensie ilości) publikowanych, bardzo szczegółowych danych, bez uwzględnienia stopnia ich selekcji z punktu widzenia adresata;

- nieprzejrzysty sposób prezentacji danych, co sprawia, że utrudnione jest uzyskanie informacji, np. na temat globalnych kwot finansowania kluczowych projektów (programów) realizowanych przez państwo;

- stosowanie niejednolitych pojęć przy publikacji tych samych danych statystycznych, np. państwowy dług publiczny - dług skarbu państwa, państwowy dług publiczny - dług sektora general government.

Z dokonanych do tej pory ustaleń wynika, że przyjęty sposób komunikowania się sprawia, że - abstrakcyjnie ujmowany - adresat społeczny, który ze swej istoty ma różny poziom wykształcenia i posiadanej wiedzy, a który ponosi przecież ciężary publiczne, jest niejako (de facto) najczęściej pozbawiony dostępu do informacji publicznej. To zaś skutkuje ograniczeniem wspominanej wyżej kontroli społecznej. Paradoksalnie więc okazuje się, że wprawdzie „przeciętny” (statystyczny) obywatel posiada dostęp do informacji o finansach publicznych, ale dane te z wielu względów są niezrozumiałe, a zatem i nieprzydatne. Warto zaznaczyć, że w grupie adresatów społecznych znajdują się także organizacje pozarządowe zainteresowane pozyskiwaniem środków publicznych na swoją działalności, które również o wiele skuteczniej mogą realizować funkcję kontrolną władzy publicznej niż jednostka.

\section{WPLYW PRZEJRZYSTOŚCI FINANSÓW PUBLICZNYCH NA POSTAWY MORALNE: ISTOTA MECHANIZMU I PRZESŁANKI JEGO PRAWIDLOWEGO FUNKCJONOWANIA}

Przedstawiona przez nas wcześniej ogólnie korelacja pomiędzy rzetelnym informowaniem społeczeństwa (w tym o finansach państwa) a kształtowaniem się odpowiedzialności obywatelskiej i umacnianiem się instytucji społeczeń- 
stwa obywatelskiego opiera się na efekcie sprzężenia zwrotnego. Jest to swego rodzaju interakcja tych dwóch czynników sprawiająca, że cały układ jest dynamiczny i podlega ciagłym zmianom. Nie można więc powiedzieć, że gdy informowanie/edukowanie społeczeństwa w obszarze gospodarowania środkami publicznymi osiagnie pewien satysfakcjonujący poziom (odrębna, aczkolwiek istotna kwestia jest jego mierzalność), spowoduje wykazywanie aktywnych postaw obywatelskich przez wszystkich obywateli. Przewrotnie można powiedzieć, że „dynamika układu charakteryzuje się stałościa”, co wynika z nieustannych procesów zmian zachodzących w sferze finansów publicznych.

Efekt sprzężenia zwrotnego w odniesieniu do relacji postawy obywatelskie - wiedza o finansach publicznych zostanie nieco dokładniej przeanalizowany poniżej, ale warto zauważyć, że efekt ten występuje również przy pozostałych parach czynników całego układu ('́rodowiska) podejmowania decyzji finansowych przez władzę publiczną.

Wyznacznikiem rzetelności (jasności) procesu komunikowania się władzy publicznej ze społeczeństwem powinny być także określone wartości moralne. Trzeba tu podkreślić, że przejrzystość finansów publicznych będzie nie tylko elementem procesu podejmowania decyzji finansowych, ale właśnie obok wartości moralnych stanowić będzie tło (wyznacznik) dla wszystkich etapów optymalnego funkcjonowania sektora publicznego ${ }^{18}$. Opierając się na tym modelu, dowodzimy, że sposób i jakość edukowania społeczeństwa oraz przekazywania mu informacji, leżące u podstaw procesu optymalnego funkcjonowania sektora publicznego, powinny odbywać się zgodnie z wartościami moralnymi, przez co jednocześnie realizowana jest przesłanka realnej (a nie tylko pozornej, w tym formalnej) jawności w zakresie m.in. finansów publicznych. W tej sytuacji zachodzą interakcje nie tylko między moralnością a edukacja, lecz także między moralnością a przejrzystością.

Wracając do wspomnianego efektu sprzężenia zwrotnego, jego analizę można zaczaćc zarówno od procesu komunikowania/informowania, jak też od postaw obywatelskich wykazywanych przez członków społeczności. Interakcja pomiędzy tymi czynnikami sprawia, że jest to układ zamknięty w tym znaczeniu, że czynniki te nieustannie oddziałuja na siebie, nie pozostają niezmienne. Na przykład rzetelne (zrozumiałe) edukowanie i informowanie o finansach publicznych wpływa na świadomość oraz ocenę obywatela dotycząca stanu tych finansów. Istotne znaczenie w tym procesie mają organizacje pozarządowe, które są jednocześnie beneficjentami informacji i pełnią rolę edukacyjna w społeczeństwie.

Szeroko pojęte przekazywanie wiedzy (informacji i danych), m.in. o: stanie finansów państwa oraz jednostek samorządu terytorialnego, podatkach, jak również wpływie (możliwościach, skutkach) obywateli na sposób wydatkowania pieniędzy publicznych przez kontrolę społeczną opierająca się na społeczeństwie obywatelskim, pobudza, kształtuje lub zmienia postawy oby-

${ }_{18} \mathrm{Na}$ temat optymalnego funkcjonowania sektora publicznego zob. szerzej w: J.M. Salachna, M. Tyniewicki, op. cit., s. 11 i n., <http://apcz.umk.pl/czasopisma/index.php/PBPS/article/view/ PBPS.2016.012> [dostęp: 8.09.2017]. 
watelskie jednostek. Można powiedzieć w tym przypadku o pewnego rodzaju stymulacji postaw obywatelskich, przykładowo polegajacej na:

- aktywizacji obywatelskiej poprzez m.in. uczestnictwo w wyborach (tu należy nadmienić, że brak akceptacji sposobu prowadzenia polityki finansowej przez państwo może prowadzić do zmiany preferencji politycznych);

- chęci aktywnego udziału w procesach kontroli społecznej poprzez uczestnictwo w organizacjach pozarządowych;

- poczuciu obowiązku ponoszenia ciężarów publicznych (podatkowych) w przypadku akceptacji prowadzonej polityki finansowej przez rządzących;

- dbaniu o dobro publiczne, identyfikowaniu się z realizowanymi celami przez państwo (solidaryzowaniu się z państwem i przyjmowaniu postaw patriotycznych).

Kwestią do rozpoznania pozostaje pytanie o to, w jaki sposób powinny przebiegać procesy informowania/edukowania obywateli jako realizacja zasady przejrzystości finansów publicznych. Jest to problematyka niezwykle obszerna i wkraczajacca poza ramy niniejszego artykułu, jakkolwiek sygnalizujemy, że kluczową rolę powinna tu odgrywać reguła adekwatności. Po pierwsze, powinna mieć ona zastosowanie i uwzględniać różne etapy kształcenia i stopnie zaawansowania (adekwatność edukacyjna), a więc nie powinna się ograniczać tylko studiów wyższych czy edukacji powszechnej. Duże znaczenie w procesie kształcenia odrywają przecież organizacji społeczne. Po drugie, należy kierowane informacje powinny uwzględniać różne - pod względem wykształcenia kategorie adresatów nieprofesjonalnych, tj. nieposiadajacych rozległej/pogłębionej wiedzy o finansach publicznych (adekwatność informacji do adresatów). Chodzi w tym przypadku o przekazywanie danych o różnym zakresie i stopniu szczegółowości.

\section{WNIOSKI}

Analizowany przez nas związek pomiędzy zasadą przejrzystości finansów publicznych (właściwym edukowanie/informowaniem o tych finansach) a postawami obywatelskim może wywoływać pewnego rodzaju dysonans poznawczy. Z teoretycznego punktu widzenia wskazana korelacja (efekt sprzężenia zwrotnego) wydaje się nie budzić wątpliwości, a przynajmniej autorzy starali się udowodnić, że taka korelacja zachodzi. Jest ona o tyle „oczywista”, o ile zgadzamy się z twierdzeniem, że wiedza kształtuje świadomość i zachowania jednostki. W praktyce natomiast, m.in. w obliczu nadmiernej ilości informacji i danych dotyczących gospodarki finansowej państwa, przy jednocześnie skomplikowanej problematyce (wielość pojęć, złożoność mechanizmów pobierania i wydatkowania środków publicznych, duża ilość regulacji prawnych itp.), kształtowanie efektywnych zachowań obywatelskich jest niezwykle trudne, a praktycznie prawie nie funkcjonuje. Naszym zdaniem nie deprecjonuje to jednak samego mechanizmu oddziaływania, a odsłania źródło problemu, który zawiera się w dwóch zasadniczych i powiązanych problemach: 
- W jaki sposób powinno się informować o finansach publicznych?

- Jak umiejętnie interpretować podejmowane przez władzę publiczne decyzje finansowe?

Nie należy zapominać, że barierę dla właściwego informowania o finansach może stanowić niechęć władzy publicznej - bezpośredniego dysponenta środków publicznych, odnoszącego określone korzyści z tego tytułu. Paradoksalnie jednak sama władza może być beneficjentem właściwej realizacji zasady przejrzystości. Wprawdzie presja świadomości społeczeństwa w kwestii oceny sposobu wydatkowania pieniędzy publicznych zmusza rządzących do uzasadniania (przekonywania) podejmowanych decyzji o charakterze finansowym, ale jednocześnie sprzyja jednak społecznej akceptacji tych decyzji, a w dalszej kolejności - aprobowaniu realizowanej polityki oraz ciagłości sprawowania władzy.

Mając na uwadze powyższe, jesteśmy zdania, że polem pogłębionych badań powinno stać się nie samo istnienie (zachodzenie) relacji przejrzystość finansów - postawy obywatelskie, ale metody i instrumenty realizacji tej przejrzystości. Inaczej rzecz ujmując: badaniu powinny podlegać sposoby przekazywania wiedzy o mechanizmach finansowych w państwie oraz ich adekwatność. Dotychczasowe funkcjonowanie zasady przejrzystości, koncentrujące się tylko na formalnym/prawnym jej aspekcie, również jej ukierunkowanie na mniej lub bardziej profesjonalnego odbiorcę (tzn. takiego, który posiada określony zasób wiedzy na temat problematyki finansów publicznych) należy zmodyfikować. Mianowicie zasada ta powinna uwzględniać konieczny przecież społeczny aspekt kontroli gospodarowania środkami publicznymi, który pierwotnie stanowił jej element w wymiarze teoretycznym. Na marginesie warto dodać, co zreszta już wskazywaliśmy, nawet profesjonaliści nieraz mają problem z odpowiednią interpretacja publikowanych danych finansowych.

Postawione pytanie o to, w jaki sposób właściwe (rzetelnie) informować o finansach publicznych, sprawia, że w nauce poświęconej tej dziedzinie należy dosyć diametralnie zredefiniować znaczenie zasady przejrzystości. Wydaje się, że podstawowym warunkiem efektywnej jej realizacji z punktu widzenia interesów obywatela jest postulat zachowania adekwatności. Chodzi zatem podstawowo o przekazywanie informacji stosownie do wykształcenia adresata, tak aby były one dla niego zrozumiałe, co wiąże się z potrzebą zachowania adekwatnego zakresu i stopnia szczegółowości. To z kolei rodzi potrzebę edukacji finansowej na różnych szczeblach kształcenia, jak również edukacji realizowanej przez organizacje społeczne.

prof. dr hab. Joanna M. Salachna

Państwowa Wyższa Szkoła Informatyki i Przedsiębiorczości w Łomży

jsalachna@pwsip.edu.pl

dr Marcin Tyniewicki

Uniwersytetu $w$ Biatymstoku

tyniewicki@uwb.edu.pl 


\section{TRANSPARENCY OF PUBLIC FINANCE \\ AND THE SHAPING OF ACTIVE CITIZENSHIP}

\section{Summary}

The discussion presented in this article aims to analyse the impact that the transparency of public finance (i.e. reliable means of providing information) has on the shaping of an active citizenship in society. The analysis was based on the critical question of how the public authority should inform citizens on the processes of collecting and spending public funds. Two aspects have been taken into account: (i) the complicated nature of public finances and (ii) the varying educational backgrounds of recipients of whom society is made of. The authors claim that the principle of transparency of public finance (i.e. informing citizens on public funding) has been inadequately implemented and may not be comprehensible from the point of view of its social addressees. In Poland, the principle of financial transparency is currently primarily focused on a relatively welleducated, well-informed citizen, although its social aspect is not entirely ignored by the doctrine. The authors believe that the manner of reporting on public funds or the State finances should be adjusted to the educational level of the widely understood public who constitute the electorate of the public authority in power. This paper is a part of an extensive research initiated by the authors, which examines the role of moral values in distributing public resources by the authorities. Non-reactive (non-empirical) research methods have been applied with a focus on the literature review, including legislative acts currently in force in Poland. 
